\title{
O INKHOUK: apontamentos sobre "a luta pela estrutura sobre o estilo"
}

The INKHOUK: notes on "a fight for construction instead of style"

Pedro Rodrigues Pousada 


\section{Resumo}

O Inkhouk foi entre 1920 e 1924 uma das mais significativas manifestações organizacionais e institucionais dos grupos da vanguarda russa e soviética; integrado num nascente Estado moderno de novo tipo e numa dinâmica revolucionária, o Inkhouk logrou demonstrar que não só era possível aos artistas manter coletivamente uma reflexão crítica e continuada sobre a linguagem inovadora e de rutura que estavam a desenvolver nas suas obras e nos seus métodos como também demonstrou que a revolução política e a sua dimensão quotidiana transformara radicalmente o significado social e simbólico do trabalho artístico de vanguarda. $O$ Inkhouk foi o momento em que o ativismo modernista se colocou em pausa reflexiva sem nunca se desligar do turbilhão dos acontecimentos.

Palavras-chave: Modernismo; Revolução, Vanguarda; Construtivismo, Suprematismo.

\section{Abstract}

The Inkhouk was, between 1920 and 1924, one of the most significant organizational and institutional displays of Russian and Soviet avant-gardes; deeply embedded in the establishment of a Modern State of a new kind and in the full core of a revolutionary dynamic, the Inkhouk was able to prove that not only was it possible for artists to collectively uphold a critical and continuous thinking on the pioneering language and cultural break that they were developing in their artistic work and in their creative methods but it also validated that the political revolution and its every day phenomena had changed the social and symbolic significance of the avant-garde work. The Inkhouk was the moment when modernist activism paused to discern itself while still fully involved in the whirlwind of events.

Keywords: Modernism; Revolution, Avant-garde; Constructivism, Suprematism. 
"Les longs ouvrages me font peur;

Loin d'épuiser une matiére

On n'en doit prendre que la fleur. ${ }^{2}$ "

La Fontaine

\title{
Ler o que já foi
}

Na contemporaneidade, parafraseando Peter Osborne, a propósito das inesgotáveis leituras e apropriações da prosa benjaminiana ${ }^{3}$, os diferentes avatares do modernismo "alimentam comentários (escritos, visuais, audiovisuais) como uma vacina num laboratório." (OSBORNE, 1998, p.28-38). Eles reanimam-se através de novas construções, persistem subliminarmente através da vida de outras imagens, de "um subtexto de pós-imagens mnemónicas." (FOSTER, 2000, p. 67). É ao descrever o esquema baudelaireano da arte como "mnemotécnica do belo" que Hal Foster faz uso desta imagem da obra artística como organização antológica; organização que não se realiza só em termos de um olhar histórico e exterior sobre uma estética passada, mas da inclinação, antagónica ou empática, da estética presente (ou da não estética, da recusa de um paradigma do belo) sobre os absolutos semânticos em que se tornaram essas imagens ${ }^{4}$. Aqui, as palavras de Ana Hatherly, que antecipam essa perceção em paralaxe, cinemática e incompleta, do fenómeno modernista.

\begin{abstract}
“A minha época é a da Antologia. Somos todos antologiadores. Não só no sentido de florilégio (no que a palavra implica de arranjo estético), mas sobretudo no que implica de sentido crítico. [...] A nossa cultura é uma cultura de informação excessiva. Sabemos muito de tudo, de tudo o que foi e está diariamente a acontecer. [...] A antologia que é a obra dum autor, é uma espécie de vasta colagem mental, uma montagem, simultaneamente paradigma do modo como a experiência se exprime e se comunica, assim como do modo como a assimilação se processou." (HATHERLY, 1979, p.9)
\end{abstract}

Vivemos sobrecarregados por essa imagem da experiência comprovada, ela é o nosso heliotropismo ${ }^{5}$ mas podemos ser felizes, produtivos até, podemos professar a integridade e a autonomia do nosso objeto mesmo que a recordação fantasmagórica do irrecuperável, do que não voltará a ver-se se confunda, seja reabilitado pelo instante presente.

\footnotetext{
“[...] Milhares de vezes eu pensei que a não-objetividade deveria ser elogiada porque graças a ela nós passamos a "ver" massas de objetos novos, de objetos que até podem ser velhos, ordinários mas cujas qualidades extraordinárias permaneciam ocultas, ignoradas." (RODCHENKO, 2005, p.106.)
}

Estas palavras explicitadas em julho de 1919 por Aleksandr Rodchenko no seu diário ${ }^{6}$, como tributo confessional ao cubo-futurismo (tributo que tem muito da "colagem mental" de que falava Ana Hatherly), subsidiam no início deste artigo um propósito: tentar compreender e contextualizar a experiência do Inkhouk/Inkhuk (Instituto de Cultura Artística de Moscovo, organismo que funcionou entre 1920 e 1924) e a subsequente produção austera do 1 음 Go construtivista; em tal grupo a bonomia 
da imperfeição orgânica, a possibilidade do falhanço, a poien como improdutividade, a culpa, a preguiça e a irracionalidade (aspectos tão característicos da boêmia artística) são separadas da ideia de modernidade por um ecrã monossêmico; neste, parece só caber o icarismo tecnocrático de artistas de um país em convulsão revolucionária, um país em que de 1919 a 1921, a revolução proletária se ergue diante da "desintegração do proletariado" e da anarquia da produção.

Esse propósito tem implicações metodológicas: primeiro, subsequente à caracterização do Inkhouk, por tornar-se necessário aferir de um modo restrito e compreensivo a genealogia da produção construtivista e da sua mediatização/receção de que foram emblemáticas as três exposições realizadas em Moscovo, respectivamente em 1919, 1920 e 1921, do OBMOKhU (Obshchestvo molodykh khudozhnikov, sociedade dos jovens artistas); e, em particular, a terceira exposição7 inaugurada em 22 de maio de 1921, participando já Rodchenko com as suas construções suspensas. Não sendo, como veremos, a única dinâmica presente no Inkhouk, o Construtivismo será, contudo, a parte mais visível e de maior impacto de muitos dos princípios activos desenvolvidos por este organismo em torno do problema artístico. Este artigo posiciona-se como um esforço, também, para integrar esse trabalho na teoria artística de língua portuguesa.

O segundo aspeto tem a ver com uma constatação: a de que o eixo Moscovo-Petrogrado terá sido um dos lugares de colisão (antagonismo) e de coligação (transformação) entre o homem real - o ser humano matriculado e reificado pelo trabalho, pelo militarismo, as "máquinas de esperar", como dizia Henri Barbusse (BARBUSSE, (1916), 2008, p.19, empurradas para o ciclo matar ou morrer, imersas no mundo dos poloi, dos muitos, dividindo-se na multidão entre camarada ou inimigo - e o homem universal do audare sapere kantiano e da Convenção de 1789 - o homem como superação dos seus próprios limites, como a encarnação de um ser mais social que cultiva a estética na sua acção cívica e a interrogação filosófica na sua relação com o mundo. E que esse push and pull se produziu num momento em que "a língua franca da prática artística modernista tornou-se a forma - e por um momento, a única forma- do imaginário social." (CLARK, 2003, p.199-210)

O primeiro cubo-futurista que "conheci" foi Vladimir Mayakowsky. Ele reaparece aqui pela sua dupla condição de revolucionário bolchevique e revolucionário modernista ${ }^{8}$; Mayakowsky foi a manifestação política, plena de contradições e de insucessos, desse antagonismo/transformação entre o homem da multidão, do transitivo mas também do transcendente, e o homem que "ainda que não conseguindo ser o sujeito que pretende ser nem viver a vida que deseja viver ${ }^{9}$ ", tem consciência de que se faz de novo (melhor ou pior) ao refazer o mundo.

Através dele podemos compreender como o modernismo agregou à imagem histórica do artista transformações e insígnias equívocas e contraditórias. Nos dezoito anos que separam o Mayakowsky de 1912 (aliado de David Burliuk e de Velimir Khlebnikov na sabotagem das soirées do simbolismo russo), do Mayakowsky de 1930, observamos o homo modernista na sua condição de sujeito desintegrado da divisão social do trabalho, exemplo (mas também negação) do homem civilizado porque capaz de romper com a normalidade burguesa; apoteose do desinibido social ou mesmo do monomaníaco atraído pela perdição e pela decadência, para quem a acção nasce da 
"raiva de irromper neste mundo para destruir e arruinar as suas criações harmoniosas" (BENJAMIN, 2002, p.228); e a biografia de Mayakowsky (mas não apenas a dele) a parecer tocar umas vezes tangencialmente outras profundamente as diversas modalidades dessa humanidade de novo tipo: reformado precoce da vida útil mas também herói do renascimento ontológico, do regresso ao primitivismo; apologista, como no seu poema épico, o Proletário voador (1925), do operador robotizado mas também crítico, como na sua peça Bania (Os Banhos, de 1929) da reificação do trabalho humano (da sua maquinização e burocratização e esse desencantamento perante a obra do progresso obtém-se, também, por via da hipérbole, isto é, da serialização do único onde no futuro da humanidade parece só caber o tédio, um engenho de esterilidade e depuração).

Esse primeiro contacto com Mayakowsky, que acabou por ser também a descoberta ainda impressionista deste período extraordinário, foi feito através do catálogo que, na altura, o Centre National d'Art et de Culture Georges Pompidou (hoje CNAM) produzira para acompanhar a exposição "Mayakowsky: vingts ans de travaux (1910-1930)". Essa exposição era o fac-símile da exposição que, em fevereiro de 1930, Vladimir Mayakowsky apresentara em Moscovo como retrospectiva da sua obra e no contexto do seu ingresso no grupo bicéfalo VAPP/AKhRR ${ }^{10}$.

Este artigo vai então começar pelo fim que, para mim, possuiu a intensidade de um princípio. No período que medeia entre a exposição e o momento do inesperado suicídio de Maykowsky, entre fevereiro e abril de 1930, já se sente um sabor de fim de festa, a sobrevivência do socialismo colocava-se na mobilização para a produção: a verdadeira revolução industrial da Rússia, com todos os seus êxitos e tragédias, iniciava-se com o $1^{\circ}$ plano quinquenal. O Inkhouk cessara ainda em 1924, o construtivismo internacionalizara-se por via de Naum Gabo mas sobretudo de El Lissitzky (que o representara no congresso de Weimar em 1922, e que definira a sua genealogia no livro Die Kunstismes: Les ismes de l'art: the isms of art de 1925 em parceria editorial com o dadaísta Hans Arp) e perdera a sua matriz radical-bolchevique ${ }^{11}$, o lefismo agonizava.

A exposição francesa decorreria de novembro de 1975 a janeiro de 1976. Mayakowsky já estava morto há cinquenta e cinco anos (e eu, por outro lado, tinha seis anos e ainda não sabia ler) e perfaziam praticamente cinquenta depois da grande mostra de Arte e Arquitectura Soviética na Exposição Internacional de Artes Decorativas, onde o edifício desenhado por Konstantin Melnikov e a sala de leitura do clube operário desenhada por Rodchenko, para além da segunda maquete conhecida da torre de Tatlin (esta teria três metros, ao contrário da original de $1920 \mathrm{com}$ cinco e possuiria uma curvatura helicoidal diferente ${ }^{12}$ ), marcariam profundamente a relação da modernidade artística soviética com o Ocidente. Foi esse evento, aliás, que trouxe pela primeira e única vez Rodchenko a Paris ${ }^{13}$.

\section{O Construtivismo reaprendido}

No seu Notes on sculpture (Part 1, Art Forum 1966), Robert Morris faz renascer Tatlin. Camilla Gray publicara dois anos antes "The Russian art experiment in Art, 18631922 ", o primeiro estudo em profundidade no qual se incluíam os cinco primeiros anos 
do envolvimento do cubo-futurismo com a revolução bolchevique, obra que, segundo Dan Graham, teria uma influência determinante em Dan Flavin e Sol Lewitt. Ainda assim estamos distantes dos estudos monográficos de Christina Lodder e John Millner, que apareceriam em 1983 e 1984; preenchido por memórias apócrifas e demasiados pontos cegos em relação ao contributo da vanguarda soviética, o primo-modernismo europeu tem na década de 60 ainda traços efabulatórios; Robert Motherwell concluíra apenas há quinze anos a sua antologia The Dada Painters and poets (1951) e com esse trabalho problematizara a descontinuidade e a aferição posicional dos fenómenos artísticos, fenómenos repletos de autores que, para falarem da mesma coisa (neste caso, da aventura Dada), usavam códigos e histórias de vida diferentes.

R.Morris posiciona Tatlin, a sua obra e sobretudo o ícone mais emblemático da modernidade dos artistas russos, a Torre do Comintern (1919-1920), como a origem de toda a escultura moderna; uma origem ainda mais apreensível do que os "Bourgeois de Calais" de Rodin, pois em Tatlin a escultura separa-se definitivamente da estatuária e nessa deslocação coloca a História da escultura em ponto morto; ao mesmo tempo em que problematiza a relação da escultura com a ideia da memória (do mito mas também do trauma) e com a ideia de monumento através do elogio de algo que ainda não tem um eixo temporal - a III Internacional é uma invenção organizacional do bolchevismo e a entrada da modernidade tecnológica e comunicacional na mundialização da luta operária, mas é um neófito com pouca história; é sobretudo uma invenção espacial pensada para ligar uma periferia que se tornou centro, a Moscovo do Bolchevismo com os trabalhadores do planeta, substituindo a ideia de Nação com a de classe - a Torre do Comintern, "o primeiro objecto de Outubro", como lhe chamaria Mayakowsky (Apud LODDER, 1987, p.61), aproxima-se de uma das polaridades do acto escultórico, associando-se à ideia de montagem e de estrutura. Morris é enfático na importância de Tatlin sobretudo por surgir como um passado que parece servir e antecipar o futuro para um presente (a cultura artística norte-americana) que se tenta subtrair do seu passado mais contíguo (a herança egotrópica do expressionismo abstrato); Tatlin é portanto:

"O primeiro a libertar a escultura do peso da representação e a estabelecê-la como forma autónoma tanto pelo tipo de imagem, ou de não-imagem que empregou como pelo uso literal dos materiais. (MORRIS, 1995, p.224)

Mas a principal aprendizagem do texto de Robert Morris talvez seja que invariavelmente as leituras, todas as leituras, estão condenadas a ser mediações; e, neste caso, os actos diferidos implicam que as extraordinárias figuras de um tempo de caos e de coletivismo apareçam em voz off, citados, fragmentados e destituídos de um quotidiano, destituídos de hesitações, de contradições e declínios; apareçam, enfim, como condensações de um absolutismo ideológico, o absolutismo modernista. Qualquer levantamento historiográfico da modernidade artística do século XX vê-se, portanto, confrontado com o carácter desigual do capital simbólico realmente realizado pelos seus protagonistas, como com as condições em que a sua atualidade, o seu tempo (a do trabalho historiográfico), em particular os poderes que controlam a economia do 
espaço-tempo, hierarquizam os grandes temas humanos (bem e mal, autenticidade e artifício, amor e ódio, ego e comunidade, natureza e tecnologia) que são, diga-se de passagem, estruturas repletas de espaços vazios submetidos aos riscos da homogeneização, do sincretismo e da analogia.

O investigador descobre, também, que a dialética entre sobrevivência e esterilidade faz do modernismo um fenómeno vincadamente logomáquico; o modernismo incorpora uma perceção antagonista, polémica do mundo mas também da sua própria identidade: "é uma inesgotável riqueza de representações, de imagens, (de objetos, de fantasmagorias) das quais nenhuma the pertence 14 " (HEGEL apud SPITERI, 2004, p. 5) e a nenhuma ele pertence. Na génese das formas artísticas modernistas denota-se, aliás, uma estratégia dilatória que pode ser consciente ou não, mas que serve à consolidação da autonomia artística, consolidação essa feita, como já vimos, em tensão e pelo lado de fora, pelo lado da receção e menos pelo lado da produção: desorientar, retardar e complicar o acto interpretativo, o esforço de delimitação e de enquadramento.

Este artigo é resultado dessa inesgotável riqueza de representações associada aos anos vinte soviéticos. Processo que nem sempre se livrou dos dualismos, criatividade versus burocracia, imaginação versus autoridade, vanguarda versus kitsch, hermetismo versus banalidade, eles e nós, etc.; com efeito, os anos vinte na Rússia Soviética tanto aparecem focados como o apogeu moderno, pré-diluviano, do imenso potencial de inovação da autonomia artística - uma porta de entrada no mundo da autorreferencialidade e da abstração, guardada por uma sentinela bolchevique; um potencial onde se agregavam dois sonhos adiados: a utopia da autonomia absoluta da arte e a utopia do fim da arte - como essa mesma década era definida em termos negativos, como sendo o momento em que a condição social do artista entrara numa precária e intermitente sobrevivência às mãos de uma cabotina e conservadora burocracia partidária. Esta deslocação pendular entre uma idade de ouro e uma fase crepuscular ainda perdura como sinopse do modernismo soviético.

Hoje estamos numa época de revisionismo e de refluxo em que, por exemplo, Malevitch é reclamado por três nacionalidades (Malewicz pelos seus pais católicos polacos nativos da Bielorússia e pela sua natalidade ucraniana e Malevitch pelo seu contributo para o modernismo russo), não pela importância que o triângulo Moscovo-Kiev-Varsóvia tivera na formação e afirmação da sua obra, mas para legitimar visões redutoras e noturnas das respetivas nacionalidades. Visões essas em que esse mesmo Malevitch é separado desse acontecimento verdadeiramente diluviano e fraturante para o mundo como foi a revolução bolchevique. Adjuvados pelas reverberações ainda incandescentes da sua sala suprematista na exposição coletiva 0.10 intensificam-se os modelos que descontextualizam essa utopia pessoal desligando as convicções monomaníacas de Malevitch do seu compromisso com a revolução e o poder soviético nos anos mais amargos e difíceis de consolidação do projeto revolucionário e que, como T.J.Clark demonstra no seu soberbo estudo sobre o período de Vitebsk e do grupo Unovis, Malevitch embarcara, assimilando e adotando (ou moldando?) o leninismo, pensamento e práxis, e o comunismo de guerra à sua teoria artística.

Entretanto o vazio das interrogações em torno da cultura soviética foi sendo ocupado e, com o assassinato da U.R.S.S., intensificou-se o processo de estudo em pro- 
fundidade deste período, trabalho esse já inaugurado por investigadores como Selim Khan-Magomedov, que podemos considerar o primeiro a fornecer um diagrama compreensível do modernismo soviético, e aquele que conseguiu salvar - não só do esquecimento mas também da destruição - um significativo património da escola soviética Vkhutemas.

Na sequência, seguem-se o russo naturalizado francês, Anatol Kopp - amigo e colaborador de Henri Lefebvre, e claramente enfatuado com a experiência da arquitectura modernista e, em particular, com o caso soviético (Quand le Moderne n'était pas un style mais une cause, 1988) -, os britânicos Christina Lodder (Russian Constructivism, 1983), John Milner (Tatlin and the Russian Avant-garde, 1984), Catherine Cooke (que revela ao Ocidente a obra de Yakov Chernikov, e que reinterpreta a obra de Ivan Leonidov e estuda em profundidade o planeamento urbano soviético), T.J. Clark, o grande estudioso da Paris do Realismo de Courbet e do Naturalismo de Manet e Paul Wood (The politics of avant-garde In The Grote utopie, the russiches avant-garde, 1915-1932, Amsterdam: Stedelijk MuseumAmsterdam, 1992), o franco-búlgaro Andrei Nakov (que se especializou na obra de Alexandra Exeter e assinou os prólogos da publicação francesa dos textos de Taraboukin).

Além desses, progressivamente seguem-se os russos pós-soviéticos emigrados: Svetlana Boym e Vladimir Paperny, Natasha Kurchanova, Margarita Tupytsin; depois, Christina Kiaer, Maria Gough, a escol mais recente trabalhando entre os espólios e as novas aquisições do Getty Research library e do Moma, que tem em depósito (o que não terá sido nada despiciendo na construção da sabedoria convencional deste período como o já notaram Hal Foster, Rosalind Krauss e Yve Alain-Blois) os diários de Alfred Barr, o primeiro norte-americano que viajou à Moscovo dos anos vinte por motivos estritamente culturais.

A força dominante na arquitetura desta historiografia é claramente anglófona, o que se demonstra pelo facto de os trabalhos de Andrei Nakov, Anatol Kopp e Magomedov estarem em posições de menor visibilidade. E temos ainda Devin Fore, Benjamin Buchloh, Leah Dickerman trabalhando a dimensão ótica e cinemática do factografismo de Vertov, Tretyakov e Rodchenko. O legado vivo e multidimensional do modernismo soviético e do construtivismo em particular possui muitas portas de acesso.

Em relação ao Inkhouk/Inkhuk, tema central deste artigo, pertence ao estudo seminal Russian Constructivism de Christina Lodder, publicado em 1983, uma das primeiras enunciações em língua inglesa da sua natureza programática feita a partir do testemunho de artistas, então, ainda sobreviventes (como, por exemplo, Vladimir Stenberg, um dos pioneiros do grupo construtivista) e de seus familiares e amigos, assim como de fontes primárias documentais obtidas nos arquivos centrais de arte e literatura, nos departamentos de manuscritos do Museu russo da então Leninegrado e da Biblioteca Lénine de Moscovo.

Será, entretanto, sem dúvida o já referido historiador soviético, Selim Khan-Magomedov, activo desde os anos cinquenta na divulgação e estudo da arquitetura soviética dos anos vinte e trinta, que, com o seu Pioneers of Soviet Architecture publicado originalmente em 1983 (Dresden, DDR) e mais tarde, 1987, em Nova lorque, quem se estabelecerá como uma referência incontornável (mas pouco mediatizada) na cultura 
historiográfica russa e internacional em relação ao carácter específico do Construtivismo russo. A título de exemplo, e para balizarmos a importância do trabalho de Magomedov, C.Lodder indica no seu texto como material de referência sete títulos que ele publicou entre 1964 e 1983 em diferentes revistas russas.

\section{O Inkhouk}

É a partir deste inquérito às fontes primárias e da sua reorganização e sistematização, trabalho realizado pelos autores referidos, que é possível dar maior nitidez à imagem desse período complexo e extraí-lo da ficção e do mito. E assim as perguntas vão-se elencando, tornando-se mais próximas do seu objeto.

Donde nascem as construções espaciais de Rodchenko, dos irmãos Stenberg, de Karl loganson, de Konstantin Medunetsky? Quando aparece Gustav Klucis nas exposições dos construtivistas? E Tatlin, o mestre deles todos e adversário ideológico de Malevitch? Onde é que o "realismo material" da obra tatlinesca e o seu antropocentrismo filo-romântico cabe na agenda dos construtivistas? Quais são os interesses e as fontes primárias dos membros do Inkhuk? Como se desenvolve esse trabalho? Por que opta Rodchenko, nos seus objetos tridimensionais (construções espaciais) da década de vinte, pela madeira e os restantes membros do grupo construtivista pelo metal? Foi esse trabalho experimental marcado pela tentativa e erro ou por um plano de acção que minimizasse o imprevisto? Houve uma aproximação intuitiva aos produtos da revolução tecnocientífica? Houve uma valorização do protótipo ou ao contrário exploraram-se as possibilidades do standard, da repetição? Que efeitos tiveram as múltiplas expressões da máquina, que se manifestava no quotidiano mesmo no mais arcaico?

Mayakowsky descrevia em finais de 1912 o futurismo como a "capa vermelha do toureiro"(Apud RIPELLINO, 1986, p.18-19), um mundo solar. Em 1920 essa capa vermelha, retângulo, geometria, monocromia predominará em absoluto sobre a narrativa de luta, de martírio que a gera: a capa já não está na arena mas tornou-se a arena. Neste período, em particular, a teoria artística acompanha em tempo real o acontecimento artístico. Teoria e práxis "apoiam-se mutuamente" segundo Andrei Nakov, se bem que Magomedov saliente que não poucas vezes a práxis avançou mais depressa. $E$ isto se deu, apesar da posteridade historiográfica alimentada por homens como Alexei Gan (que introduziria no grupo construtivista o termo Tektonika para substituir o de Faktura que fora introduzido na cultura pictórica russa em 1912 por David Burliuk e Mikhail Larionov $^{15}$ ) e Nikolai Tarabukin (com o seu artigo "Do Cavalete à máquina" publicado em 1923 pelo Proletkutl) terem criado a sensação de que a teoria lançou as palavras de ordem e definiu as iniciativas metodológicas dos artistas.

O Inkhouk foi a expressão mais conseguida dessa reciprocidade teórico-prática (e das suas contradições); foi uma experiência desenvolvida num espaço de quatro anos numa altura em que as relações entre vanguarda artística e Estado e entre produção artística e produção social se intensificaram; nasce num quadro de grande complexidade e, como veremos mais detalhadamente, é uma aliança heterodoxa e frágil entre a cultura modernista pré-revolucionária e as lógicas produtivistas associadas ao arranque político de uma nova fase da organização económica, política e social da Rússia 
Soviética. As suas actividades desenvolveram-se na cidade de Moscovo, capital do poder soviético e o impulso inicial das suas actividades ocorreu no período final da guerra civil e no desencadear da Nova Política Económica em 1921.

Nesta fase parece confirmar-se que o fim da separação e da hierarquização das artes e a organização científica do trabalho são reflexivos da convicção, tão cara aos primos-modernistas, que o lugar da transformação política radical é o lugar natural da transformação artística (FOSTER, 1993, p.173-180). Os artistas só podem estar dentro da arca de Noé e esta é a Revolução social. Como anos mais tarde Michel Ragon observaria em relação aos eventos de Maio de 1968, "a manifestação política revela-se uma forma superior de criação" (ROSENBERG, 1991, p.109) e essa coincidência entre intransparência (a intangibilidade do visível; a desfamiliarização, o choque) e a História (dos grandes acontecimentos que necessitam conviver com as micropolíticas do quotidiano) implicou que o modernismo tornasse a sua permanente revolução formal, a crise das suas relações sociais de produção, parte integrante do problema político: o modernismo de guerra entra em cena.

Como comenta Yve-Alain Bois, a Rússia soviética foi "um laboratório em que tudo o que era pertinente para a arte foi experimentado até ao ponto da exaustão." (BOIS, 2006, p.54)

Hoje o Inkhouk constitui um momento essencial de um processo histórico que, no sincretismo nómada que faz viajar retrospetivas de velhas glórias do Modernismo pelas diferentes latitudes dos dispositivos museológicos, parece-nos derrisório. Foi uma das interfaces fundamentais da conjunção histórica da autonomia artística por via da reformulação da estética (da experiência e da produção do belo) e da autorreflexividade dos próprios artistas (isto é, da especialização que fizeram dos resultados da sua produção e do ambiente discursivo que ajudaram a erguer).

Podemos parafrasear Mayakowsky, que afirmava que "a revolução do conteúdo é impossível de pensar sem uma revolução da forma" e sublinhar que o Inkhouk tentou cumprir a tarefa de tornar a revolução de conteúdo (artístico, estético e político) indissociável de uma revolução da forma. O seu êxito foi de tal ordem que fez extinguir em poucos anos a sua finalidade programática. Gertrude Stein comentava que a América (os Estados Unidos) fora moderna antes de ser modernista ${ }^{16}$; sobre a Rússia soviética podemos dizer que esta foi modernista antes de conseguir ser moderna e no processo de modernização acabou por ocultar, obsolescer e menorizar a sua herança modernista.

Há em toda esta dinâmica de eventos um personagem que merece ser relevado pela sua centralidade. Trata-se de Anatol Lunacharsky, dirigente entre 1919 e 1929 do Narkompros, acrónimo de Comissariado do Povo para a Educação e Cultura; Lunacharsky descrevia-se a si próprio como um "intelectual entre os bolcheviques e um bolchevique entre os intelectuais"; apesar das suas reticências em relação à torre Tatlin e de considerar que os artistas de esquerda eram incapazes de contribuir para a fundação de uma arte revolucionária "da mesma forma que um mudo era incapaz de ter um discurso revolucionário" (KHAN-MAGOMEDOV, 2013, p.42), este intelectual-político terá um desempenho crucial no desenvolvimento das relações por vezes tumultuosas e equívocas entre as vanguardas artísticas extraídas do cubo-futurismo e o poder Sovi- 
ético. O seu empenho na matéria cultural explica-se segundo Gérard Conio:

“[...] para além do seu gosto pessoal, do seu ecletismo e da sua abertura de espirito, [...] para além da necessidade de unir a inteligência e de lançar um povo até então atrasado e servil na direção do saber" (CONIO, 1987, p. 221; c.f. HOLTER, 1970, p. 262-282.)

Como uma perceção estratégica de que - através do estabelecimento de relações culturais, isto é, através da salvaguarda e apoio ao diálogo cosmopolita e transcontinental que existira antes da revolução e que, apesar dos anos da guerra, perdurava entre as vanguardas europeias - era possível quebrar o cordão sanitário imposto em março de 1919 pelo Presidente Georges Clemenceau e rapidamente adotado pelas potências vencedoras e vencidas da I Guerra Mundial assim como pelas nações emergentes do desmembramento do império Russo, como a Polónia, a Finlândia e as repúblicas bálticas ${ }^{17}$.

Há uma estratégia política de salvar a Rússia primeiro do intervencionismo e depois do isolamento através da sua vanguarda artística. O modernismo atravessava mais facilmente a linha Curzon do que as iniciativas soviéticas de normalização diplomática com a Europa.

Para além do modernismo também é verdade que os negócios saltavam o arame farpado. Os contactos comerciais regularizaram-se, mas o reconhecimento político do Estado Soviético continuava adiado. O fiasco em 1922 da Conferência de Génova (onde as potências da Entente, em particular a Grã-Bretanha, a França e os Estados Unidos tentam impor contrapartidas políticas e de ingerência budgetária para integrar o Estado Soviético como membro pleno no novo mapa geopolítico europeu e mundial) e o tratado subsequente de Rapallo entre a Alemanha de Weimar e o Estado Soviético dão início a um difícil processo de normalização. Resultado provável desse clima de desanuviamento entre dois Estados tidos como párias pelas potências vencedoras e também uma das plataformas de maior visibilidade da estratégia de usar a cultura como instrumento diplomático seria a primeira exposição de Arte Russa inaugurada em outubro de 1922 na Galeria berlinense Van Diemen ${ }^{18}$. Mas o que importa relevar é que se os artigos de consumo, a tecnologia ocidental atravessam a fronteira, é o modernismo do Unovis, do Vkhutemas, do Construtivismo, é esse primeiro produto cultural de facto desta nova sociedade que vai resgatá-la dos estereótipos anticomunistas e provar ao público de Berlim e Amesterdão em 1922 e de Paris em 1925 que o Estado da ditadura do proletariado é capaz não só de produzir e desenvolver artefactos civilizacionais como de inventar uma nova linguagem para as formas artísticas e para a comunicação de massas.

Aleksandr Rodchenko já notara no seu diário em julho de 1920 essa atracão ainda diferida e fragmentada, pela aparente simultaneidade e solidariedade entre os fenómenos políticos e culturais na Rússia soviética:

"Alguns holandeses representantes dos Comunistas chegaram ao Congresso da III Internacional e foram ter com Kandinsky. Pediram-lhe mais material sobre a arte Russa e explicaram que o faziam a pedido de artistas holandeses. Kandinsky, como sempre, enviou muitas fotografias do meu trabalho e de Varst (Varvara 
Stepanova)...Não sei se chegaram lá. No ocidente está tudo parado como antes da guerra, os mesmos velhos Picassos e Matisse. Eles todos dizem que estão a olhar para a Rússia com uma esperança enorme, que trocariam sem hesitar de lugar connosco..." (RODCHENKO, 2005, p.205)

A exposição em si refletia uma coexistência artificial entre os diferentes grupos do modernismo russo, mas o seu sucesso foi considerável entre a comunidade artística alemã e europeia. Lassos Kassak, Moholy Nagy, Kurt Schwitters, Theo van Doesburg, são alguns dos que percorrem as diferentes secções da exposição, sendo estes dois últimos, por exemplo, e certamente impressionados positivamente pelo que viram, planeiam uma viagem nunca concretizada à terra dos sovietes. Aconselhada por Marcel Duchamp, Khaterine Dreier adquire uma das construções espaciais (1920) de Konstatin Medunetsky (então membro activo do 1ำ grupo construtivista).

Mas regressemos à orbita do nosso tema: o instituto foi criado em março de 1920 como uma emanação da secção Izo (de Iskusstvo-Arte) do Narkompros, sendo colocado sob a direção de um grupo significativo de artistas, arquitetos e ativistas culturais ligados à história do modernismo russo, à reforma do ensino artístico pós-revolucionário, à modernização dos espaços museológicos, e aos problemas da criação na idade da socia, a sua orgânica interna incluía um Presidium,"uma direção colegial eleita" (KHAN-MAGOMEDOV, Op.Cit., p.53), constituída por Liubov Popova, Aleksandr Rodchenko, Varvara Stepanova, Robert Falk e chefiada na sua primeira fase por Wassily Kandinsky. Ele está, aliás, associado às atividades da secção de Arte Monumental do IZO desde 1918, tendo partilhado responsabilidades nesta secção com Tatlin, Sofia Dymshits-tolstaia (aluna e assistente de Tatlin na execução da famosa torre do Comintern), Malevitch e Olga Rozanova; curiosamente nem Malevitch nem Tatlin aparecem ligados às actividades mais significativas do Inkhuk; o caso de Malevitch entende-se pelo seu envolvimento no Unovis de Vitebsk entre 1920-1922, tendo após essa data, especificamente em 1923, assumido em Petrogrado a direção de uma segunda instituição com as mesmas características, o Ginkhouk que havia sido estabelecido na primavera de 1921; ao contrário do seu congénere moscovita que se dissolveu em 1924, o Ginkhouk prolongaria as suas atividades até 1932.

Tatlin terá participado como convidado em algumas conferências a partir dos finais de 1921, já depois de concluído o debate histórico sobre construção e composição que mitografou a experiência do Inkhuk como um Think Tank greenbergiano antes de Greenberg ${ }^{19}$. O primeiro lugar onde a autorregulação disciplinar e a metalinguagem das práticas artísticas pós-cubistas e pós-futuristas começaram a ser conteúdos de um debate interdisciplinar que pretendia superar a reflexão isolada e improcedente e socializar os seus resultados tornando-os operativos, úteis e produtivos na construção da nascente sociedade soviética. Com efeito, pela primeira vez na história moderna, um Estado reservava meios logísticos e recursos financeiros, num período particularmente difícil e indeterminado da sua existência, para que os sectores mais avançados da criação artística procedessem a uma investigação coordenada sobre a produção e receção da visualidade moderna. Kandinsky assinará em março de 1920 o programa original onde se lê que: 
"O objetivo (dos trabalhos do instituto) é esclarecer as leis internas, positivas na base das quais as obras estéticas se realizam em cada uma das esferas da arte e em conexão com os resultados obtidos estabelecer os princípios da expressão artística sintética."

Esse trabalho seria dividido em três abordagens metodológicas que tratariam da relação estrutural entre matéria e forma artística; analisariam a construção como um componente fundamental da criação artística e estudariam a composição artística como efeito da causalidade construtiva e encarnação do princípio artístico. Na sua posição programática Kandinsky tenta estabelecer uma coerência situacional para o modernismo na Rússia revolucionária propondo a secularização do artista-xamã. 0 seu método procura legitimar a obra artística como uma interface entre cosmos e ego, entre autonomia e heteronomia. Era quase impossível que esta interpretação intuitivo-metafísica não suscitasse crescentes críticas pelos sectores mais radicais do Inkhouk que defendiam uma abordagem mais sintagmática das práticas artísticas.

Quando Kandinsky assume as suas funções diretivas a vanguarda debate-se entre o passado e o futuro, "é como um projétil situado entre a terra e a lua, encontrando-se, num estado de gravidade zero" (SCHLOWSKY (ou CHLOVSKI), apud GIUSI, 1978, p.85). $\mathrm{Na}$ literatura, na música, no teatro e nas artes visuais a "velha arte", como a designavam os cubofuturistas, a arte antediluviana ainda se mantinha ativa, vestindo a aparência da novidade, mas para os artistas de esquerda essa complacência do moderno com o anacrónico era intolerável, pois consideravam o passado como uma ameaça para a continuação da própria vida.

Assim os sectores mais avançados e politicamente informados dos cubofuturistas russos encontram na revolução o acontecimento e a oportunidade histórica de resolverem a separação do intelectual russo em relação ao seu povo; a relação já não pode ser a do mestre plenipotenciário e do aluno passivo e as experiências anteriores à Revolução de Gontcharova e Larionov com os Lubok, as xilogravuras populares russas que se reverberarão nos Stencil e nas vinhetas dos cartazes Rosta de Mayakowsky, o trabatho de Alexandra Ekster em Kiev com artistas populares, o conceito de Faktura extraído da redescoberta dos ícones russos são um prenúncio dessa intenção. Os adversários de Kandinsky acabam por assumir a rutura em novembro de 1920, seis meses depois do início das atividades. $E$ fazem-no na mesma altura em que Lénine assina o decreto que estabelece o Vkhutemas, a Bauhaus soviética (em atividade desde 12 de Outubro). Essa rutura implicou a criação do grupo independente liderado por Aleksandr Rodchenko, que se tornaria progressivamente maioritário levando a saída de Kandinsky e dos seus aliados em janeiro de 1921 (como já acontecera com Marc Chagall em Vitebsk em 1919, suplantado por Malevitch).

Esta fração do Inkhouk preconiza um estudo do processo artístico e do seu produto final, a obra de arte, que problematize as implicações históricas da interrupção do elo entre significado e significante, isto é, do que representou a crise da representação mimética e o advento do objecto (pictórico) antinarrativo e autoreferencial; um estudo, também, capaz de refletir sobre a insegurança ontológica da obra (o fim da sua condição de objeto único) e sobre o que essa insegurança significava como sintoma da fase terminal e irreversível a que, supostamente, e numa leitura marcada pela teleologia 
hegeliana, as artes da visão, no seu processo histórico de autoimunização, haviam chegado. A descrença no futuro da arte, não é, contudo, consensual entre os que defendem uma abordagem objetiva e o grupo Objetivista de Liubov Popova será a expressão desse desacordo. Numa das suas intervenções no Inkhuk o arquiteto Aleksandr Vesnin expõe o problema:

\footnotetext{
"A minha reação à participação do artista na produção é positiva mas um artista deve tratar dos seus assuntos e o principal desses assuntos é o efeito (psicofisiológico) da forma na consciência humana. O engenheiro moderno criou objetos extraordinários: a ponte, a máquina a vapor, o aeroplano, a grua...o artista moderno deve criar objetos que são iguais a esses em poder, intensidade e em potencial no contexto do seu impacto psicofisiológico como elementos organizadores da consciência humana." (VESNIN apud SENKEVITCH, JR., 1990, p.173-174)
}

Esta aparente disjunção entre os que acreditam que o artista se pode refundar noutra coisa exterior à sua história e os que detetam nessa opção o risco do diletantismo é, aliás, um dos aspetos interessantes do construtivismo lido como tendência e menos como movimento orgânico, aspeto que foi repetidas vezes assinalado por Magomedov; quer Popova com o seu trabalho cénico antinaturalista no teatro de Meyerhold quer El Lissitsky, Gustav Klucis, Ilya Chasnik polarizados para a questão modernista em Vitebsk ao lado de Malevitch e no seu grupo Unovis, viriam a tornar-se referências essenciais do construtivismo e da sua capacidade de mobilização para a esfera da produção social sem, contudo, pertencerem à génese do grupo; talvez imunizados da ortodoxia pelo facto de terem sido expostos a outra, a suprematista, e não terem soçobrado aos seus cânones.

É oportuno, aqui, destacar o carácter digressivo e mesmo dilatório que cunhou o termo construtivismo no seu período real de existência. O construtivismo nasce para a nomenclatura da História da Arte do século XX como neófito extraordinário da vanguarda cubo-futurista russa, em março de 1921 no Inkhuk. Mas se a compressão semântica do construtivismo está associada a essa circunstância espaço-temporal e à espécie de guia de marcha em que é implicado como possibilidade empírica, a verdade é que há mais de quatro anos que o construtivismo se tornara uma realidade ubíqua e viajante ${ }^{21}$. Ou seja, o termo foi articulado por um grupo específico de artistas de vanguarda para reivindicar numa etapa histórica e num lugar preciso que a arte chegara a um ponto crítico; se não havia como vimos consenso quanto ao desenlace dessa crise era unânime que o estado era de não retorno.

O Construtivismo assinalava, portanto, a etapa histórica do fim da pintura de cavaelte. Mas já, antes do seu baptismo oficial, o construtivismo possuía uma acepção sociológica ${ }^{22}$, isto é, de identificação e de percepção por parte de uma comunidade - a vanguarda artística russa e as suas periferias constituída por críticos e historiadores - de uma "relação nova, diferente entre a forma e o material" (Tatlin - ou, em Velimir Khlebnikov, entre o poema e as palavras), uma relação em ruptura com a velha lógica entre forma e conteúdo e entre imagem e ilusão. Aliás, a metodologia desenvolvida por Tatlin direciona-se no sentido de destacar as "propriedades físicas, tácteis e dinâmicas dos materiais" (FREDRICKSON, 1999, p.5), de reconhecer que a iniciativa formal depen- 
de das características orgânicas dos materiais: a forma faz-se a partir do material e não em detrimento deste.

Desde que em 1914-16 (Tramvai V, 0.10) Tatlin expusera os seus Contra-relevos de Canto, que esta relação nova entre a forma e o material, a especialização materialista, a crítica do objecto artístico como visão passiva e remota da realidade, a defesa do artista como um organizador que punha os materiais a funcionar ao serviço da actualidade (como começa a acontecer nas correcções plásticas e aparatos extraparietais com que intervêm no ambiente mundano do Café Pitoresque de Moscovo) tinham-se tornado imperativos conceptuais e as imagens fortes donde, nos anos vinte, se extrairia a síntese heteróclita e dialéctica entre o americanismo, a ontologia maquinista da arte e os Budietlyane (os vagueantes do futuro concebidos por Khlebnikov para caracterizar o modernismo anti-pastoral da vanguarda russa de 1910).

O termo viajou, portanto, de mãos em mãos, transitando das experiências plásticas e da prática quotidiana dos ateliers, da boémia literária e artística das duas grandes cidades russas (Petrogrado e Moscovo) para as páginas de diferentes manifestos (como por exemplo, o Manifesto Realista de N. Gabo e o Manifesto Produtivista do grupo de Rodchenko, textos que são contemporâneos mas adversários), conduzindo as suas aparições públicas entre as salas de exposições e os grupos informais (Armazem, 0'10, Café Pitoresque, OBMOKHU), solidificando-se não só como conceito poético e plástico mas como visão (e reorganização) filosófica da vida humana através de glosadores com perspectivas muitas vezes antinómicas, algumas incompletas, outras desviantes e mesmo generalistas.

Num texto publicado no primeiro número da revista Lef (1923), Mayakowsky explica a importância histórica do Construtivismo, situando-o como uma produção especificamente russa com um enorme potencial de exportação: "Pela primeira vez, uma palavra nova na arte, o construtivismo, não veio da França, mas da Rússia. [...] Para tanto, os artistas franceses devem vir à nossa escola". Mayakowsky separa-o em dois tempos, que são reflexivos das mudanças operadas em outubro de 1917 e da subsequente guerra civil: "o construtivismo dos artistas, que transmudam o ótimo e o necessário fio de ferro e a lata em estruturas inúteis" e este juízo é sintomático da descrença, manifesta como programa ideológico na revista LEF, em relação ao artista como um tipo social inventado pela revolução burguesa de 1793 e que, impregnado de contradições, encontra, na segunda década do século XX a sua resolução dialéctica, " [...] o construtivismo que entende a elaboração formal do artista apenas como engenharia, como um trabalho indispensável para dar forma a toda a nossa vida prática." As palavras certeiras de Mayakowsky são auxiliadas e contemporâneas do texto de Nikolai Taraboukin, que descreve a investigação artística pura como "Construtivismo analítico." Este, por sua vez, apoiava-se na nomenclatura que Guillaume Apollinaire inventara em 1913 para caracterizar no seu Meditations Esthétiques (lido certamente por Udaltsotova, Lentulov e Alexandra Exeter) o Cubismo de Braque e Picasso como Cubismo científico.

Mas novamente divago, o que se assinala aqui é que, com a saída de Kandinsky que se mudará para a comissão fundadora do GAKhn, a academia estatal das ciências artísticas, a tecnocracia assume, autoritariamente, agonisticamente o seu ascendente histórico, ainda que frágil e reversível no campo da criatividade artística. 
A génese artística autorreflexiva coloca-se em observação. Como não ver nos debates em torno das relações e oposições entre composição e construção, que se iniciam no dia $1^{\circ}$ de janeiro de 1921 e que se prolongam por nove sessões, os vestígios da herança ideológica deixada pela Filosofia da Composição de Allan Poe (1846)? O poeta revela os seus truques de mágico: o desvendamento "da marcha progressiva" do "modus operandi", "das engrenagens, [...] dos truques" (POE,1989, p.35) com que a obra chega ao seu fim; neste caso específico observamos não apenas artistas mas também arquitectos a estudarem o produto do seu trabalho e a tentarem definir um enquadramento para a sua dimensão experimental, especulativa, a entenderem a obra como processo mas também como a geografia conceptual da condição artística (não só se interrogando sobre os limiares do que é ou não arte, e sequer se esses limites são necessários mas sobretudo o que torna uma obra contemporânea e necessária ao seu tempo, o que a torna uma causa do seu tempo).

A análise de obras concretas, as conclusões e relatórios estenografados, as teses propostas por Nikolai Ladovsky23, Vladimir Krinsky, Popova e Bubovna, as opiniões e comentários de Rodchenko, Stepanova, Babitchev entre tantos outros, opiniões testadas com factos pictóricos concretos, conduzem para uma apreciação laboratorial do a priori da prática artística: optimização dos recursos (Varvara Stepanova:"Nós seguimos a linha de minimização dos elementos inúteis da composição.") e sobredeterminação das propriedades do medium para suprimir o inútil e relevar os elementos que produzem o efeito plástico (a forma). O programa original revelar-se-ia, portanto, insuficiente para confrontar o campo artístico e os seus produtores com uma época de descontinuidade e de suspeita em relação às noções de coesão colectiva e de continuidade cultural cada vez mais entendidos como instrumentos representacionais da dominação de classe.

Em concreto, o modernismo russo cubo-futurista, iconoclasta nascido entre 1908 e 1912 no eixo Paris-Berlim-Moscovo, as suas diferentes vertentes e os seus agentes mais jovens e mais radicalizados pronunciavam-se sobre a inevitabilidade de um fim (a derrisão da utopia da autonomia absoluta da arte diante das violências da História) e de um renascimento já não fundado na artesania e na ambiguidade estética, mas no culto da politecnia e do trabalho interdisciplinar. Um dos aspetos mobilizadores das conferências e discussões do Inkhuk era a de que existia um corte irreconciliável e (no otimismo ingénuo dos seus protagonistas) irreversível entre esses dois tempos que se exprimia na transformação do atelier, espaço de criação individual, num laboratório baseado nas vantagens da gestão científica do trabalho e na taylorização dos métodos de produção.

Em 1921 coincidem não só a migração do Inkhuk para a esfera do Conselho superior da economia nacional como a crítica da criação artística individual. As nove assembleias gerais do grupo de trabalho de análise objectiva encarregam-se de definir (e depurar) as diferenças metodológicas e ideológicas entre construção e composição agenciando como princípios activos da nova arte (que passará a ser uma não arte ou uma pós-arte) a organização da matéria, a disposição coerente, o plano estruturado, a recusa do inútil, a funcionalização do estético. Boris Arvatov, apologista de uma conceção do artista como um ginasta da forma e da técnica, definia, por exemplo, as opções 
geracionais que restavam aos artistas: aos mais velhos o ativismo político, e aos mais novos o politécnico 24 ; as novas competências são assim definidas por ele: "O artista (produtivista) calcula, desenha, planeia cientificamente cada um dos seus passos, ele considera os seus resultados sociais, ele trabalha lentamente, cessa de depender dos seus humores, das suas empatias e antipatias subjectivas - numa palavra o processo de produção artística é socializado." (Boris Arvatov apud LODDER, Op.Cit, p.106).

Osip Brik, por seu lado, afirmaria que a sociedade só devia apoiar os artistas na medida em que estes eram contribuintes dedicados ao seu desenvolvimento: "Não trabalha, não é alimentado", e aos mais irredutíveis, aos pintores de cavalete, um dos irmãos Stenberg reserva-lhes o destino dos contrarrevolucionários (Apud SENKEVITCH JR., 1990, p. 173-174).

O que se concretiza a partir de março de 1921 para os membros do Inkhouk é a ideologização do artista moderno como um construtor-produtor capaz de integrar no seu trabalho a supremacia da acção sobre a imagem: a arte já não é a socialização do improdutivo, a harmonização estética entre o raro (incomum) e a novidade (o diferente), mas um participante ativo na luta contra a alienação, contra a privação material, a iliteracia cultural e contra o obscurantismo. É um jogar às escondidas entre hermetismo e didatismo. Para o sistema de crenças dos diferentes colaboradores do Inkhouk, a arte adquirira um nível de desenvolvimento performativo e conceptual, que lhe permitia ser duplamente a antecipação estética do modo de vida socialista e a manifestação concreta e quotidiana de um monismo entre arte, técnica e sociedade. A arte, através dos seus sectores mais avançados e conscientes, refunda um mundo que, por sua vez, a regenera. O monismo social e técnico, profissionalismo e conhecimento, cognição e sensibilidade, adquirem uma envergadura sociológica, o artista ingressa no socialismo como um novo tipo social. Este é um aspeto, aliás, recorrente nas metáforas modernistas que circulam muito em torno de um nascer de novo, um novo ego, e da radicalização de um ser de novo (de um novo homem).

O instante renovado e a heroificação do absolutamente novo são os referentes de um modo diferente e menos canónico de convergência da experiência pessoal do artista moderno com a do homem moderno. No projeto modernista o sujeito humano (exorcizado na figura do Poeta, do Artista) apropria-se do mundo re-representando-se, reeducando-se com as potencialidades da atualidade presente. Mas este é um trabalho filosófico e material difícil em que a autenticidade nem sempre é consistente e durável. Nem sempre o exorcista é senhor de si mesmo ou da sua tecnologia.

Já em 1923 Louis Lozowick observava como a lei dos contrastes se repetia na visão doutrinária com que os artistas russos metaforizavam a máquina, posicionando-a como um quadro organizativo da atividade humana baseado na precisão, na ordem e na otimização dos recursos (LOZOWICK, 1923, p.202). Lunatcharsky chamar-lhe-ia o "macaquear do tecnicismo", um encantamento diletante por um mundo desconhecido (a fábrica) que ignorava o carácter reificante da especialização e divisão do trabalho industrial: diz então Lozowick que, enquanto "a Inglaterra da época de consolidação da Economia política capitalista, da revolução industrial e do centralismo urbano inventa o paisagismo como conteúdo privilegiado das artes visuais", a Rússia agrária, o "Egipto russo 25 ", como lhe chamaria em 1928 Mayakovsky (MAYAKOWSKY apud KOPP 1990, 
p.91), é um arquipélago de cidades horizontais (a sonharem com Berlim e Chicago) onde o rural "joga às escondidas" (BENJAMIN, 2004,p.161) com o urbano, um mosaico de nacionalidades, inventa o construtivismo.

Num texto fundamental, "God is not cast down"26 , T.J.Clark (CLARK, 2001,p.225297) fornece-nos uma série de materiais úteis para compreendermos a génese da ideologia produtivista que caracterizará o desfecho programático do Inkhuk; refere sintomaticamente às teses de Lénine sobre Propaganda para a produção publicadas, em finais de novembro de 1920 no Pravda:

\footnotetext{
"Reduzir o espaço (nos principais jornais, Izvestia, Pravda) dedicado à política e aumentar o espaço para propaganda da produção. [...] Popularizar os problemas da eletrificação e o sistema de Taylor. [...] Um uso mais sistemático e extensivo do cinema na propaganda da Produção. Registos fonográficos sobre o tema. Apresentações de diagramas e cartogramas nos clubes operários, nas salas de leitura das aldeias, nas ruas, etc. Billboards e placards a serem expostos nas fábricas, nas oficinas, nas escolas técnicas." (LÉNINE apud CLARK, Op.Cit., p.227-228)
}

Refere-se igualmente às resoluções do IX Congresso do Partido em abril de 1921, que se mobiliza para iniciar um plano económico unificado; mas é sobretudo na ênfase dos problemas da deserção e da redução das forças produtivas, do absentismo e da incompetência, a valorização do trabalho obrigatório e da militarização do trabalho, que se denotam nos discursos políticos de Bukharin e Trotsky deste período27 que podemos encontrar o fundo político da radicalização agonista do Inkhouk. A realidade concreta: o Estado operário precisa de uma força coesiva, integrada, unificada, como uma máquina de precisão. O problema: os futuristas não podem ficar fora de jogo, têm que encontrar a sua utilidade, têm que justificar as recompensas sociais e simbólicas que obtêm numa época de crise e de racionamento.

O que se implicava neste monismo de técnica e ideologia era a refundação do estatuto social do artista e das suas competências num âmbito análogo ao que significara em Paris o fenómeno sociológico que vai do Salon des Refusés de 1863, passa pela sociedade 1874 e se conclui no Salão dos Independentes de 1884; esse trabalho realizar-se-ia fazendo deslocar do contexto exclusivista da arte para a esfera pública aquilo que constituía os ganhos metodológicos e iconográficos da experiência modernista; são sobretudo os artistas que protagonizam essa deslocação (ou abandono) e não é tanto a arte, que, separada do seu objeto milenar (a representação do mundo), se torna uma imagem rarefeita, diferida (como de facto acontece nas sessões do Inkhouk) de processos combinatórios e de questões formais.

O aprofundamento e desenvolvimento de tais questões se potenciam nos novos suportes de comunicação, suportes também de socialização e politização intensiva: a fotografia, a construção de livros e as práticas editoriais ligadas à conceção de revistas de vanguarda, os novos dispositivos cénicos, expositivos e arquitetónicos e finalmente o cinema e a rádio, a partir dos finais da década de vinte; o utilitarismo e o experimentalismo, a tentativa e o erro, a forma provando o seu valor em ação, a linguagem técnica do laboratório e do escritório apoderam-se dos debates, os questionários e o levantamento de dados refletem esse enfase metodológico no tratamento quase estatístico 
quer do material existente nas coleções recentemente nacionalizadas quer nas obras produzidas pelos membros do Inkhouk.

Mas é importante relevar que há sempre um contrapeso como, aliás, vimos com o caso de Popova e Vesnin, à crescente identificação desse monismo com o maquinismo; a experiência ganha um valor autocorretivo. $O$ desejo de imitar a máquina, de maquinizar a autoperfeição e a perfeição social, ego e totalidade como gestos deterministas, planeados, antecipados e capazes de restituir o homem à sua humanidade perdida constitui um subtexto, se quisermos a porção transitória, "infinitamente mediatizada" do que foi o modernismo. Mas insistamos que esse desejo de imitar algo sem vida foi também um processo de transferência antropogenética - exemplificada na máquina que sente dos futuristas (BANHAM, 1979, p.183-184), nos mecanomorfos de Francis Picabian (BAKER, 2007, p.220), na máquina com lágrimas dos surrealistas, máquina arcaizante, sofrida, reactiva e com memória, uma máquina que vive como igual.

E um processo de reagrupamento metafórico de valores como construção, autenticidade e realismo - o construtivismo com um pé de fora do eixo utilitarista e politécnico, fundado num empirismo intuitivo e aceitando o risco da ineficácia e do improdutivo exemplifica-se por Tatlin, Karl loganson, Liubov Popova, Gustav Klucis, El Lissitzsky.

Pode-se conseguir construir a obra, mas isso não significa que ela funcione. Saliente-se que Tatlin não pode, no plano ideológico, ser transportado para a rendição tecnolátrica e o nihilismo utilitarista com que os jovens construtivistas posicionavam a máquina, culminando-a como o estádio superior da evolução humana. Percebemos melhor o seu posicionamento ao lermos uma análise de 1932 sobre Rodchenko e o 1 Grupo Construtivista, na qual se observa que "Ele (Rodchenko) seguiu o caminho de um pensamento geométrico e acabou por não entender o meu" (LODDER, Op.Cit., p.213). A sua hipótese metodológica é de que a "forma experimental pode gerar a função prática ${ }^{28 "}$ e que a sua Torre para o Comintern e os Proun de Lissitszky serão imagens fortes. Na visita que George Grosz realiza à Rússia em 1922 descobrirá um Tatlin diferente do campeão da modernidade que esperava encontrar:

\footnotetext{
"Encontrei mais uma vez Tatlin, o grande tolo. Estava a viver num pequeno, antigo e decrépito apartamento. Algumas da galinhas que criava dormiam na sua cama, outras punham ovos num canto... Quando tocava a sua balalaika...dava a impressão, não de um ultramoderno Construtivista mas de um pedaço da velha e genuína Rússia, como extraído de um livro de Gogol; e nessa altura instalava-se um humor melancólico no seu quarto." (GROSZ, 1998, p.179-180)
}

O verdadeiro Tatlin era "um bardo da Hélice, [...] um Caçador do Sol" quixotesco como o descrevia Veimir Khlebnikov (Apud MILNER, 1984, p.120), que não estava tão enfatuado pela máquina como heroificavam os seus adeptos europeus, em particular os dadaístas berlinenses Raoul Haussamn, o próprio George Grosz e John Heartfield.

No no 1 da revista Veshch em 1922, Lissitzky e llya Ehrenburg afirmariam que o "utilitarismo primitivo é-nos estranho" (Veshch, n1ㄴ, Berlin,1922, p.229). O editorial era reflexivo da conferência que Lissitzsky pronunciara em finais de 1921 no Inkhuk e que fora uma tentativa mal-sucedida de incorporar o seu conceito Proun ${ }^{30}$ no mundo 
das formas construtivistas; o sectarismo do 1ำ grupo construtivista continuava a ler a materialidade do Proun como derivada de estruturas parietais ao serviço da história da pintura, isto é, da acumulação pictórica e menos como um terreno vago ocupado pela vontade de construir (organizar) os sintomas artísticos das transformações sociais; por defeito do antagonismo programático do grupo de Taraboukin e Rodchenko em relação à pintura, Lissitzky, que é visto pelos seus interlocutores como um sucedâneo da escola pictórica de Malevitch, um "infiltrado", não lograra agregar o espaço-tempo do Proun à consciência construtiva; a pretensa modernização da gesamkunstwerk, a revolução estética, como o cruzamento imersivo de diferentes saberes da cultura artística, terá que esperar pela internacionalização do construtivismo proporcionada pelas revistas G (Material zur elementaren Gestaltung-1923-1926), de Hans Richter, e Merz (1923-1932), de Kurt Schwitters.

Em 1924, num texto que assina para o n 8/9 da revista Merz-Nasci (número, aliás, de que será um dos editores tipográficos a convite de Kurt Schwitters), El Lissitzsky acentua e clarifica essa separação criticando uma concepção que limita as potencialidades do construtivismo a um finalismo maquinista:

\footnotetext{
"Estamos fartos de ouvir falar perpetuamente da máquina, máquina, máquina quando se trata da produção artística moderna: A máquina não é mais do que um pincel, e um pincel bem primitivo... Todas as ferramentas põe forças em movimento, forças que se orientam no sentido da cristalização da natureza amorfa, [...], a máquina não nos separou da natureza. Através dela nós descobrimos uma nova natureza nunca até então conhecida...o nosso trabalho é um prolongamento da natureza...toda a forma é a imagem instantânea e cristalizada de um processo...toda a obra é um momento estacionário, um interface..."(LISSITSZKY, 1924, p.2;C.f MERTINS, 2011, p.16-23)
}

$\mathrm{Na}$ análise de Lissitzsky incorpora-se a mesma racionalidade autocrítica de que a pintura cubista fora pioneira ao desmentir o aparente e nesse processo destruindo a forma para construir a realidade; mas subverter a perceção da realidade para relevar a sua inorganicidade, como o havia sido o repertório cubista não muda o facto de a realidade ser em si demasiado inapreensível e incolecionável. E esse é um problema da representação cubista - a complexidade e densidade dos seus códigos, a sobreposição e interacção de camadas de leitura - o pictórico, o textual, a collage, o gráfico -, apesar de pretender aproximar-se do mundo tal como ele não é para o olho humano, acentuou o mundo como uma não imagem.

Será esse um problema de que os contrarrelevos de canto de Tatlin, assim como o ex-nihilo magnético do Cherni Kvadrat (Quadrângulo Negro), de Malevitch, apresentados na famosa exposição 0.10 de Petrogrado (1915), tentavam dar resposta ao mesmo tempo em que se constituíam como propriedades da modernização. O desenho técnico, axonométrico, a negação da mão intuitiva, a estrutura, a linha sem dimensão autográfica, a cor ao serviço da geometria e dos códigos ideológicos constituem os momentos seguintes, momentos que vão encontrar as suas novas fontes nutritivas no projecto, na engenharia, na mecânica, na cidade, no trabalho pós-humano, anónimo, destituído de vestígios biográficos e finalmente na revolução. 
O discurso de Lissitszky integra-se num momento da vanguarda artística em que esta se torna reflexivamente consciente dos limites das suas propostas perante a ilegibilidade do informe, perante um mundo constituído por coisas que são da ordem do biológico, do inorgânico, do invisível, do generativo, do acidente e do acaso. A máquina e o seu mimetismo não são suficientes para integrar e controlar o fora de campo, o imprevisível da experiência. As leis gerais que definem as forças de que as máquinas tentam ser a versão inteligível e humana - a versão com que o homem julga submeter a natureza -

tornar-se-ão importantes motivos temáticos para que Lissitzky e também Tatlin recentre o seu entendimento das relações entre tecnologia e arte.

Como se veria com a aparente reabilitação de Rembrandt, de que Mayakowsky fora acusado por Rodchenko 31 , o problema era, contudo, bem mais complicado. Vimos como os modernistas soviéticos do Inkhuk e do Unovis queriam cessar o tipo de ocularidade que a linguagem de formas da pintura de Rembrandt proporcionara; mas há algum niilismo ao se queimarem etapas num país agrário, subdesenvolvido, onde o analfabetismo grassava na maioria da população e onde a sua literacia visual, quando existia, não incluía qualquer contacto com esse tipo de imagens; declarar o fim da pintura figurativa num país maioritariamente constituído por camponeses analfabetos e monopolizado pela sobrevivência económica básica tem qualquer coisa de espúrio e indigno.

No fundo essa remissão ontológica manifestava um conjunto de intenções díspares: por um lado havia um sentimento muito forte de irreversibilidade emprestado pela revolução e pelo trauma da guerra civil: nada do passado era recuperável ou válido e havia, isso sim, que antecipar o momento no qual a memória humana não reuniria mais as condições culturais e psicológicas para compreender como Arte essas imagens, as de Rembrandt e as dos primo-modernistas; queriam, enfim reiniciar a História da Arte a partir do fim da pintura de cavalete, no fim da representação como determinante da qualidade artística das imagens e dos objetos e por consequência na separação semântica entre o visível e o visual, e entre forma (como se diz) e conteúdo (o que se diz).

A supernova nasceria de um buraco negro. Esse radicalismo talvez seja o aspeto menos interessante (e importante) dos membros do Inkhuk ${ }^{32}$. O lado mais duradouro foi o modo como se manifestaram preocupações intradisciplinares (no interior da pintura, da escultura, da arquitectura) e interdisciplinares (de pontos de vista e de metodologias comuns), em relação ao problema da autonomia artística, entendido como um mal conjunturalmente necessário; preocupações de carácter revisionista e autocorrectivo: a arte (e sobretudo os artistas, os seus produtores) tinha (tinham) que descobrir o seu lugar na história, e redefinir a sua função social, mas tinha (tinham) que o fazer inventando, a partir da experiência da modernidade e da modernização, dos seus instrumentos de crítica.

Ela, por sua vez, tinha que ser autorreflexiva na medida em que resolvia a distância 
em relação ao mundo dos Poloi, salvaguardando e integrando o carácter hermético e incompreensível das suas linguagens na experiência quotidiana - a recusa da verosimilhança e do mimetismo tinha que se manter intacta ao mesmo tempo em que o vazio criado era preenchido por esse novo tipo de iconografia (cubomórfica, pós-cezanniana e pós-cubista). Em tal tipo, a metáfora - a associação de ideias - era feita dos novos modos de comunicar, de construir, de trabalhar, dos novos meios de socialização, das novas relações de poder, dos novos tipos de mobilidade, dos novos sons, materiais e imagens que caracterizavam a experiência moderna das primeiras décadas do século XX.

\section{Conclusão}

Chego ao fim desta reflexão sem conseguir concluir de um modo assertivo, mas não queria fazê-lo sem antes recorrer à ajuda de Maria Gough (GOUGH, 1998, p. 9192), que logo no início do seu estudo sobre Karl loganson me colocou perante uma perplexidade duradoura. Foi aí que se acentuou para mim o carácter inovador da experiência do Inkhuk: uma linguagem estrangeira praticada por "excêntricos", "esotéricos", chamar-lhes-ia T.J.Clark, e hoje falada nas múltiplas variantes da fala por quem, na década de vinte, ainda não existia.

Outra lição: o que no presente nos aparece como incompreensível, inútil, idiota mesmo, pode ser reencontrado no futuro como antecipação, mas se a bizarria tem direito à esperança, os que a estranham e a ridicularizam têm direito a hesitar e mesmo à animosidade. Uma força não existe sem a outra. Diz-nos então Maria Gough que a tradutora russa Rita Rait-Kovaleva, nas suas memórias, conta que durante a inauguração de uma das exposições OBMOKHU, onde vigorava o grupo construtivista, ela e um grupo de amigos penduraram por brincadeira os seus casacos nas construções espaciais lá expostas; Mayakowsky, indignado, explicou-lhes que aquelas estruturas não eram cabides, mas obras que indicavam novas relações entre as formas, contrariavam a ideia de volume e incluíam o vazio e a dissolução do exterior e do interior dessas superfícies como características plásticas, expondo os materiais a condições nunca dantes experimentadas; em suma, avançavam um novo entendimento da tecnologia e da estética. Mais tarde compreendeu melhor as palavras do poeta soviético quando, ao traduzir o texto de Gertrude Stein sobre Picasso, encontrou uma parte que se referia ao período da Grande Guerra; contava Stein que em Paris, no Boulevard Raspail, Picasso e ela se depararam com um comboio de canhões pintados com padrões camuflados. Diante dessas pinturas, Picasso reagiu afirmando: "[...] nós é que fizemos aquilo! Aquilo é Cubismo" (PICASSO apud STEIN, (1938), s.d., p.22). Há outra citação (aliás, as citações prosperam neste texto como bactérias...) que se impõe aqui como um auxílio metodológico:

\footnotetext{
"Um poema que cante sobre arranha-céus, dirigíveis, submarinos pode ser escrito no canto mais longínquo de uma província russa num papel amarelecido e com a mina partida de um lápis. De modo a inflamar a imaginação prodigiosa dessa província é suficiente que esses arranha-céus, dirigíveis e submarinos se encontrem na América. $\mathrm{O}$ mundo humano é o mais portátil de todos os materiais. (TROTSKY, 1923) “
} 
Talvez se encontre aqui, na consciência explosiva da escassez e da imaginação como pathos dessa escassez, a explicação para a minha empatia.

\section{Referências bibliográficas}

ALMEREYDA, Michael (Editor). Night wraps the sky- writings by and about Mayakowsky, New York: Farrar, Straus and Giroux, 2008.

ANDERSON, Perry. As Origens da Pós-modernidade, Lisboa: Edições 70, 1998.

BAKER, George. The Artwork caught by the tail, Massachusets: The MIT Press, 2007.

BANHAM, Reyner. Teoria e Projeto na primeira era da máquina, São Paulo: Editora Perspectiva, 1979.

BARBUSSE, Henri. Le Feu, Paris: Bellenus, (1916), 2008.

BEAUJOUR, Elizabeth Klosty. Zamiatin's We and Modernist Architecture, Russian Review, Vol. 47, No. 1. (Jan. 1988).

BENJAMIN, Walter. Sobre arte, técnica, linguagem e política, Lisboa: Relógio d'água, 1992.

Zentralpark, Fragments sur Baudelaire In Charles Baudelaire, un poète lyrique à \冈apogée du capitalisme, Paris : Éditions Payot, 2002.

Imagens de Pensamento, Liboa: Assírio Alvim, 2004.

BOIS Yve-Alain. Art Forum, Feb 2006.

BOYM, Svetlana. Common places: Mythologies of everyday life in Russia, London: Cambridge University Press, 1994.

BUCHLOH, Benjamin. Cold War constructivism. In GUILBAUT, Serge (Ed.). Reconstructing modernism: Art in New York, Paris and Montreal, 1945-1964, Cambridge: MIT Press, 1990.

From Faktura to Factography, October, Vol. 30. (Autumn, 1984).

CONIO, Gerard. Le Constructivisme Russe, Lausanne: Editions l'Age de L'homme, 1987, p. 221.

CLARK, T.J. Farewell to an idea, Episodes from a history of modernism, New haven \& London: Yale University Press, 2001.

El Lissitzsky in Vitebsk. In PERLOFF, Nancy \& REED, Brian (Ed.). Situating El Lissitzsky, Vitebsk, Berlin, Moscow, Los Angeles: Getty Research Institute, 2003.

ELIOT, T.S. Tradition and the Individual Talent. In Selected Essays; London: Faber and Faber limited, 1951.

FOSTER, Hal. The return of the real, Massachusets: The MIT Press, 1993.

Design and Crime, London: Verso, 2000.

FREDRICKSON, Laurel. Vision and Material Practice: Vladimir Tatlin and the Design of Everyday Objects, Design Issues, Vol. 15, No. 1. (Spring, 1999).

GIUSI, Rapisarda. (Ed.), La Fábrica del actor excêntrico (FEKS), Barcelona: Editorial Gustavo Gili, 1978. 
GOUGH, Maria. The Laboratory of Constructivism: Karl loganson's Cold Structures, October, Vol.84 (Spring 1998).

GROSZ, Georges. Georges Grosz: An autobiography, Berkeley: University of California Press, 1998.

HATHERLY, Ana. O Espaço crítico do Simbolismo à Vanguarda, Lisboa: Editorial Caminho,1979.

HAUSER, Arnold. Teorias da Arte, Lisboa: Editorial Presença, 1978.

HOLTER, Howard R. The Legacy of Lunacharsky and Artistic Freedom in the USSR, Slavic Review, Vol. 29, No. 2. (June 1970).

KHAN-MAGOMEDOV, Selim. L'Inkhouk naissance du Constructivisme, Paris: Infolio, 2013, p.42

KIAER, Christina. Rodchenko in Paris, October, Vol 75. (Winter 1996), Massachusets: The Mit Press.

Boris Arvatov's Socialist Objects, (Massachusets: The Mit Press, October, Vol. 81. (Summer, 1997.

The Russian Constructivist Flapper Dress, Critical Inquiry, Vo 28, №1. (Autumn 2001), Chicago: University of Chicago Press.

KOPP, Anatol. Quando o Moderno não era um estilo mas sim uma causa, São Paulo: Nobel: Editora da Universidade de São Paulo, 1990.

LANCHNER, Carolyn. Fernand Léger: American Connections. In LANCHNER, Carolyn (Ed.). Fernand Léger. New York: Museum of Modern Art (MoMA), 1998, p.15.

LELEU, Natahlie. Mettre le regard sous le contrôle du toucher - Répliques, copies et reconstitutions au XXe siècle: Les tentations de l'historien de l'art, Les Cahiers du Musée national d'art moderne, no.93, Paris, Autumn 2005.

LISSITSZKY, Elezard, Merz-Nasci n8/9, Hannover, Abril-Julho 1924, p.2, texto em alemão e em francês.

LISSITZKY-KUPERS, Sophie. El Lissotzkij: Pittore, Architteto, Tipografo, Fotografo, Roma: Editori Reuniti, 1992.

LODDER, Christina. Russian Constructivism, Haven and London: Yale University Press, 1987.

El Lissitzky and the Export of Constructivism. In PERLOFF, Nancy \& REED, Brian (Ed.), Situating El Lissitzsky, Vitebsk, Berlin, Moscow, Los Angeles: Getty Research Institute, 2003.

LOZOWICK, Louis. A note on Modern Russian Art, Broom Magazine, February 1923. Acessado em http://bluemountain.princeton.edu/bluemtn/cgi-bin/bluemtn?a=d\&d=bmtnaap192302-01.2.17\&e=-------en-20--1--txt-IN-----\#

MALEVITCH, K. Le Suprématisme en Peinture, 34 Dessins, (1920). In LICHTENSTEIN, Jacqueline (Ed.), La Peinture Textes Essentiels, Paris: Larousse, 1995.

MERTINS, Detlef. Modernity unbound, Londres: Architectural Association London, 2011.

MILNER, JOHN. Vladimir Tatlin and the Russian Avant-garde, New Haven and London: Yale University Press 1984.

MORRIS, Robert. Notes on Sculpture. In BATTCOCK, Gregory. Minimal Art- A cri- 
tical anthology, Berkeley: University of California Press, (1968), 1995.

OSBORNE, Peter, Philosophizing beyond philosophy- Walter Benjamin reviewed

In Radical Philosophy 088 (March/April 1998).

POE, Edgar Allan. O corvo seguido da Filosofia da Composição. Lisboa: Ulmeiro, 1989.

RIPELLINO, A.M. Maiakóvski e o teatro de Vanguarda, S.Paulo: Editora Perpsepctiva, 1986.

RODCHENKO, Aleksander. In LAVRENTIEV, Alexander (Ed.), Experiments for the Future - Diaries, Essays, letters, and other writings, Nova lorque: MoMA, 2005.

ROSENBERG, Harold apud JENCKS, Charles. The post-avant-garde. In PAPADAKIS, Andrew. The New Art, London: Academy editions, 1991.

SENKEVITCH, JR., Anatole. "The Sources and Ideals of Constructivism in Soviet Architecture". In ALLISON, Nicholas H (Ed.). Art Into Life: Russian Constructivism 19141932, New York: Rizzoli International Publications, 1990.

SPITERI, Raymond. Envisioning Surrealism in "Histoire de l'OEil and La femme 100 têtes" In Art Journal, Vol. 63, No. 4. (Winter, 2004).

STEIN, Gertrude. Picasso, (1938), Lisboa: Vega, s.d.

TROTSKY, Lev. Literatura e Revolução, Capítulo 4: O Futurismo (1923). Texto consultado na sua versão inglesa em 30.6 .08 no site http://www.marxists.org/archive/trotsky/1924/lit_revo

1 "Aqui as minhas visões vivas erguem-se enormes: a luta pela estrutura sobre o estilo, o cálculo de feixes de metal/ (...) Esta costela lembra-nos uma máquina (...) por estes cabos e fios eu sei que já nos retiramos da idade do carvão e do vapor ". MAYAKOWSKY, Vladimir. A ponte de Brooklyn (1925). In ALMEREYDA, 2008, p.202-206. Nossa tradução.

2 In Novo Almanach de lembranças Luso-brazileiro para o anno de 1899, Lisboa: Livraria de António Maria Pereira, 1898.

3 Nós admitimos que também subalugamos a sua prosa.

4 A análise de Hal Foster transporta-nos para relação desenvolvida por T.S. Eliot no seu Tradition and the Individual Talent entre a criatividade e a tradição. Esta ùltima surge no texto de Eliot como uma estrutura poderosa extremamente produtiva e indutiva; uma estrutura que não pode ser resumida negativamente a um obstáculo, à realidade coerciva da fronteira, ou a uma vulgarização e canonização dos limites do que já foi feito; se possuísse essa orgânica a tradição nunca seria uma realidade sobrevivente. A tradição é uma construção diz-nos Hal Foster. A proposição de Eliot de que o seu poema de Wasteland (1922) é a prova de fogo, é então de que a tradição é um processo crítico e histórico de apagamento, de recordação, de coleção e de rejeição; é a clivagem entre crise e estabilidade, entre o carácter inexplicável e desviante do texto e o emaciamento e sujeição do texto a um significado, a uma hipótese de comunicação, de inteligibilidade. Eliot observa, também, que o passado mantém uma presença espectral e impertinente nessa aprendizagem que 0 presente faz da eternidade. Em cada geração o passado tem uma existência simultânea com a experiência que se concretiza. A contestação do seu poder é contraditoriamente uma afirmação da sua permanência e do lastro e ascendência que vai realizando sobre os processos que lhe sucedem e que o pretendem reprimir. O presente é também o enunciado mnemónico, inconsciente diferido do que já foi feito em termos de criatividade e de subjectividade. Eliot recompõe (ou, talvez, rectifique e aperfeiçoe) assim a oposição baudelairiana entre um passado antigo e irremediavelmente histórico e uma actualidade que procura conceber-se e espacializar-se como eternidade sem o conseguir ver- dadeiramente. (C.f. ELIOT, 1951, p. 21-49.)

50 uso deste termo remete para outro leitor da tradição, mas um leitor materialista histórico: Walter Benjamin. (BENJAMIN, 1992, p.159.)

60 diário de Rodchenko é uma valiosa fonte de informações, (parcial está claro e por isso com alguns défices que repercutem o cosmos do par Rodchenko-Varvara) do processo de transformação do cubo-futurismo russo desde que Rodchenko chega em 1915 a Moscovo, proveniente de Kazan onde estudara Arte, e conhece Tatlin, Popova, Exter, Udaltstova e Malevitch (por quem não iria nutrir grande simpatia: "era do género quadrado, com olhos antipáticos, pouco sincero, preconceituoso, cheio de si próprio e sectário".In RODCHENKO, Op.Cit, p.78.) entre outros nomes; perpassam nas notas avulsas de Rodchenko a entropia das relações humanas, as idiossincrasias de Tatlin e de Mayakowsky, maiores que o mundo (Rodchenko descreve-se como um neófito em dívida com Tatlin, pela (...) abordagem da minha profissão, dos objectos, dos materiais, da comida, de tudo na vida, e essa influência deixou a sua marca em toda a minha vida. In RODCHENKO, Op.Cit., p.79), a degradação das lealdades e do sentimento de pertença, a sensação nostálgica de que algo se tornou irreversivelmente pobre e desconexo na intimidade entre grandes artistas.

7 A Galeria Tretyakov, Moscovo, tem um simulacro deste evento e refere-lo como sendo da segunda exposição e alguma bibliografia regista apenas duas exposições. É de notar que as fotografias do showroom de 1921 se têm repetido invariavelmente quando se fala do grupo construtivista sendo do ano seguinte as reacções mais próximas do evento e em concreto quando El Lissitzky e llya Ehrenburg publicam no $n^{01 / 2}$ da revista Veshch (Objecto) dois clichés da famosa sala; uma dessas fotografias surge reproduzida por Laszlo Kassak e Moholy Nagy no Új Muvèszek Konyve (O livro dos novos artistas) também de 1922; para além dessas imagens, as de Tatlin e dos seus assistentes do IZO de Petrogrado posando diante da maquete do Monumento à III Internacional apresentado em Dezembro de 1920 na Sala da União dos Sindicatos em Moscovo, por ocasião do VIII Congresso dos Sovietes, as 
fotografias e desenhos técnicos dos quiosques e projectos de mobiles arquitectónicos com fins de agitação e propaganda, as arquitecturas cénicas que celebrizaram nomes como Rodchenko, Gustav Klucis, El Lissitzky, Aleksandr Vesnin, Liubov Popova, todo esse material constitui a cristalização imagética com que qualquer estudante de artes se depara ao folhear a bibliografia sobre esta época histórica.

80 único poeta com que os bolcheviques puderam contar quando ainda eram uma força política clandestina, "o poeta da água fervida" mas também o poeta cabeça-globo whitmanesco.

9 Tomo emprestada a caracterização que Arnold Hauser (HAUSER, 1978, p.70-71) faz do artista moderno, romântico: "é, inevitavelmente, um fracasso, um indivíduo que não é realmente o que gostaria de ser e que passa o seu tempo a descrever o homem que não consegue ser, a vida que não consegue viver, o significado da vida que não consegue compreender".

10 Associação de Escritores da Rússia Revolucionária/Associação de Artistas da Rússia Revolucionária, futura charneira do doutrinário Realismo socialista. 11 Aqui Christina Lodder (LODDER, 2003, p.31-32 e p.36-37) disputa no seu artigo, El Lissitzky and the Export of Constructivism (1998-2003) a tese de Benjamin Buchloh que apontara Naum Gabo como 0 autor material da extirpação ideológica, da "subversão ocidental", do construtivismo; Lodder descreve Lissitzky como o grande exportador do construtivismo e quem, nas palavras dela, "lançara uma versão modificada do conceito" defendido pelo grupo de Rodchenko, terá sido ele a propor entre 1922 e 1923 numa conferência em Berlim dois momentos fundacionais para o construtivismo, o Unovismo em Vitebsk e o OBMOKhU em Moscovo. Veja-se também, BUCHLOH, 1990, p.85112.

12 C.f. LELEU, 2005, p.84-103.

13 C.f. KIAER, 1996, p.3-35.

140 texto citado refere-se ao olho humano: "esta noite, este interior humano (...) nós vislumbramos esta noite quando olhamos para os seres humanos no olho- para dentro de uma noite que se torna horrível."

15 BUCHLOH, 1984, p.85-86.

16 "So it begins to be reasonable that the twentieth century whose mechanics....whose standardisation began in America, needed the background of Paris, the place where tradition was so firm that they could look modern without being different."(STEIN Apud LANCHNER, 1998, p.15)

17 Percebemos melhor esse clima político se recordarmos que em 1921 Max Ernst não pode estar presente em Paris na inauguração da sua exposição na Galeria Au sans pareil (Maio-Junho) porque as autoridades britânicas de ocupação da cidade de Colónia o tinham colocado como suspeito de simpatias bolcheviques (em 1919 andara a vender sem grande sucesso a sua revista Dada "Die Schammade" à porta das fábricas da cidade). Ou podemos também lembrar a viagem clandestina através da Finlândia e plena de peripécias de George Grosz à Rússia onde passaria seis meses regressando sem grande entusiasmo pelo processo revolucionário, desencantado mesmo.

18 Essa exposição migraria em 1923 para o Museu Stedjlik de Amesterdão, a mesma instituição que acolheria em 1992, praticamente 70 anos depois, a exposição de Grote Utopie onde se procederia a um balanço dos vinte anos "oficiais" do modernismo russo-soviético (1912-1932).

19 "O Inkhuk foi uma instituição sem precedentes: uma instituição artística apoiada pelo Estado e criada apenas com o propósito de conduzir a pesquisa sobre o modernismo na arte. (...) O Programa de investigação do Inkhuk exemplifica a definição de modernismo articulada por Clement Greenberg: a atenção autocrítica dada por artistas avançados iniciada na segunda metade do século dezanove, aos materiais, aos processos do fazer e às estruturas da receção que são inerentes e exclusivas de uma forma artística particular. Mas distinguindo-se do modernismo greenbergiano o princípio da construção como é desenvolvido nos debates do Inkhuk em 1921 resultou numa crítica à noção tradicional da arte como criação individual." In (KIAER, 2001, p.194195). Nossa tradução.

20 No original em russo lê-se Ounovis (Outverdjdiéné Novogo v IskousstviéAfirmação do Novo na Arte).Cf. (MALEVITCH, 1995, p.891-895).

21 "O termo construtivismo não se tornou comum senão a partir de 1921 e os arquitetos não 0 adotaram formalmente senão a partir de 1924, mas a investigação e as experiências que prepararam o caminho para o Construtivismo enquanto tendência arquitetónica eram já evidentes em 1919 e 1920." (Nossa tradução). (BEAUJOUR, 1988, p.51).

22 Aceção que facilitou na sua vida póstuma e transcontinental uma crescente homogeneização das diferenças que só os estudos mais recentes tem evidenciado assim como uma série de sincretismos e de omissões. No seu escorço-diagrama das origens, influências e flutuações convergentes e divergentes do
Modernismo, o primeiro diretor do MoMA, o norte-americano Alfred Barr situa 0 ano de nascimento do Construtivismo em 1915

23 "A construção técnica é a união de elementos materiais elaborados; união essa que se faz segundo um plano determinado para se obter um efeito de força. (...) 0 critério principal da construção .... facto de que ela não contém materiais e elementos inúteis. (...) A principal diferença com a composição é a hierarquia, a interdependência." In KHAN-MAGOMEDOV, Op.Cit., p.61

24 Christina Kiaer (KIAER, 1997, p. 105-118) demonstra que Arvatov não foi apenas um dos apologistas de uma abordagem produtivista da cultura artística mas desenvolveu uma reflexão profunda sobre o objecto de consumo no quotidiano (em russo byt) socialista, inclusive Arvatov consegue emancipar-se do taylorismo que dominará as concepções de Alexander Gastaeev, outro apologista do politecnicismo. Svetlana Boym explica que a o termo "byt"que se tornou corrente entre os simbolistas e a vanguarda russa descrevia o "reino da estagnação e da rotina, de um quotidiano transiente mas sem transcendência"; em antagonismo com "bytie", o território da demanda espiritual, "byt" tornou-se um símbolo desprezado de tudo o que era retrógrado, sujo e desorganizado. (Cf. BOYM, 1994).

25 A marcha das Brigadas de Choque: "Na obscuridade/ Do Egipto Russo/ Como pregos/ Planta lâmpadas.

26 Neste capitulo T.J.Clark analisa o grupo Unovis (Malevitch, Lissitzsky, Chasnik, Sueitin, Khidekel) de Vitebsk e as suas relações metodológicas e ideológicas com o leninismo e o comunismo de guerra e fá-lo focando-se na análise formal, semântica, contextual de uma fotografia onde aparece em plena rua dessa cidade maioritariamente judia da Bielorussia um quadro suprematista de propaganda ideológica realizado por el Lissitzky encostado a um edificio industrial; o quadro semi-abstracto, uma prototipia dos seus Prouns (de que T.J.Clark assinala outros dois outros trabalhos semelhantes, um óleo sobre contraplacado (Gorod, cidade de 1919-1920) e um desenho a grafite e guache (Proun1E: Gorod-Cidade- também da mesma data), é um apelo às armas para o regresso à produção: "As mesas de trabalho das oficinas e das fábricas aguardam-vos. Avancemos a Produção."

27 CLARK, T.J. Op.Cit.pp.258-261.

28 Cf. ANDERSON, 1998.

29 Fac-símile digital consultado em: http://digitalgallery.nypl.org/nypldigital/ dgkeysearchdetail.cfm?trg $=1 \&$ struc|D $=1042956 \&$ image $I D=1563292 \&$ total $=36 \&$ num $=0 \&$ parent $\_i d=1042950 \& s=\&$ notword $=\& d=\& c=\& f=\& k=1 \& s S c 0-$ pe $=\&$ sLevel $=\&$ sLabel $=\& \mid$ word $=\& \mid$ field $=\&$ sort $=\& i m g s=20 \&$ pos $=5 \&$ snum $=\& e=w$ 30 Nas actas da conferência que pronunciara no Inkhouk em Outubro de 1921, define-se de um modo mais completo o ethos da sua arquitectura imersiva: "Proun é o nome que nós demos à estação que fica no caminho para a construção de uma nova forma. Cresce num terreno fertilizado pelos cadáveres da pintura e do seu artista...quando nós vimos que o conteúdo da nossa tela já não era pictórico, que tinha iniciado uma rotação...nós decidimos dar-Ihe um nome apropriado. Chamamo-Io PROUN...as formas, com que 0 Proun faz o seu assalto ao espaço, são construídas não segundo uma qualquer estética mas de acordo com o material disponível. Nas estações iniciais dos Prouns esse material é a cor que é tomada como o aspecto mais puro do estado energético da matéria na sua encarnação material...o Proun avança na direcção de um novo espaço e ao dividi-lo, atravessando o tempo, nos elementos da primeira, segunda e terceira dimensões, ele (o proun), constrói uma imagem poliédrica mas uniforme da natureza."Texto datilografado. Arquivo Lissitzky no Arquivo central de Literatura e Arte do Estado.(LISSITZKY- KUPPERS, 1992, p.326-332)

31 Nas suas notas Rodchenko recorda como ao abandonar o grupo LEF Mayakowsky "amnistiara Rembrandt "(RODCHENKO.Op.Cit.), isto é, atrelara o comboio do modernismo na cronologia da História da Arte, entendida esta como um sistema de categorização de estilos e de autores.

32 Até porque o Estado proletário se sentia no direito de exigir os seus William Kent, de proporcionar as condições para que estes aparecessem e até de sonhar com Gustave Courbet.

33 In TROTSKY, Lev. , Capítulo 4: O Futurismo (1923). Texto consultado na sua versão inglesa em 30.6 .08 no site http://www.marxists.org/archive/trotsky/1924/lit_revo 


\section{Autor}

\section{Pedro Rodrigues Pousada}

Artista Plástico, doutor em Arquitetura pela Universidade de Coimbra (FCTUC) em 2010, mestre em Teorias da Arte pela Faculdade de Belas-Artes da Universidade de Lisboa (FBAUL) em 2012

Lisboa, Coimbra, Portugal pedro-pousada@netcabo.pt 